\title{
The Scientific Community
}

\section{Sir James Taylor}

The author traces the growth of science through the ancient world, the 'New Learning' and the Royal Society, the Industrial Revolution, and the two world wars; and discusses the origins of learned societies and professional bodies, the institutionalization of science, and the exponential increase in numbers of the scientific community. The accusation that scientists are responsible for social ills is examined, and wider roles and new horizons for scientists in the future are suggested. Paper covers $£ 1.05$ Science and Engineering Policy Series

\section{John Dalton}

\section{Critical Assessments of his Life and Science}

\section{Arnold Thackray}

John Dalton (1766-1844) was an archetypal 'new man' of Industrial Revolution science. His life illuminates the changing social background and cultural meaning of science in the first stages of its professionalization. Arnold Thackray, a leading authority on Dalton, has searched out previously unknown documents from many archives for his study of the central aspects of Dalton's social context and intellectual achievement. 8 illustrations $£ 5.75$ Harvard

\section{Newton and Russia}

\section{The Early Influence, 1698-1796}

\section{Valentin Boss}

At the end of the seventeenth century knowledge of the heliocentric concept of the universe was almost non-existent in Russia outside Kiev and Moscow, and St Petersburg, the cradle of Russian science, had not been built. Three decades later, however, Isaac Newton's revolutionary doctrines had taken root in the St. Petersburg Academy, and a nation long identified with backwardness, superstition, and ignorance had vaulted into the modern era. This is the first study in any language to examine Newton's influence in Russia. Frontispiece 47 illustrations $£ 9.50$ Harvard

\section{Oxford}




\title{
H. G. J. MOSELEY: THE LIFE AND LETTERS OF AN ENGLISH PHYSICIST, 1887-1915
}

\author{
John L. Heilbron, Associate Professor of History at Berkeley
}

This book is a full record of Moseley's brief and brilliant career. It gives instructive detail about Eton, which, as $\mathrm{Mr}$ Heilbron shows, offered a more opportunity for acquiring a foundation in science than its emphasis on Greek and games would suggest; about Oxford, a scientific backwater in Moseley's time; and about Rutherford's thriving laboratory at the University of Manchester.

$$
225 \text { pages } £ 5.70
$$

\section{MOSES MAIMONIDES ON THE CAUSES OF SYMPTOMS}

\author{
Edited by J. O. Leibowitz and Shlomo Marcus
}

The subject of this book is a treatise by Maimonides (1135-1204)-Jewish philosopher and at one time physician to the court of Egypt-commonly known as De causis accidentium. Presented here for the first time in a multilingual critical edition that includes the Hebrew, Arabic and medieval Latin texts as well as commentaries on each of them.

$$
250 \text { pages } £ 4.75
$$

\section{University of California Press}




\section{OFFICERS AND COUNCIL OF THE BRITISH SOCIETY FOR THE HISTORY OF SGIENCE}

1973-4

President

Dr J. A. Ghazdeoott

Vice-Presidents: D. Gminton, Esq.

DR M. P. Crostand

DR J. D. North

LT-CDR D. W. Waters

Hon. Secretary: Dr M. P. EARLss

Hon. Treasurer: G. L'E. TURner, Esq.

Hon. Editor: DR R. Fox

Hon. Programme Secretary:

H. G. L. Bevan, Esq.

Council: $\quad$ DR E. J. Arron

DR W. H. Brock

Dr R. A. Buchanan

Dr J. K. Crerlung

Protrssor A. R. Hall

Dr M. B. Hrase

Dr A. G. Keller

Dr R. G. Olday

Dr A. D. Orange

Profresor P. M. Rattanat

DR M. J. S. Rudwick

Fr J. L. RussarL

$$
\text { Ex-libris }
$$

WILLIAM C WAKE 


\section{THE BRITISH JOURNAL FOR THE HISTORY OF SCIENCE}

\section{Volume vi Part Iv December 1973 No. 24}

Garolyn Iltis: The Leibnizian-Newtonian Debates: Natural Philosophy and Social Psychology

JoHn R. MirlbuRn : Benjamin Martin and the Development of the Orrery

Robert K. DeKosky: Spectroscopy and the Elements in the Late Nineteenth Gentury: The Work of Sir William Grookes

Note:

G. E. Perrin: Lavoisier, Monge, and the Synthesis of Water, a Case of Pure Coincidence?

Essay Review:

Joseph Fourier, 1768-1830

Book Reviews

Books Received

Collections II: The Crawford Collection

Obituary

Notes on Contributors

Report of the Council

PUBLISHED BY THE BRTTISH SOCIETY FOR THE HISTORY OF SGIENCE

Registered Office: 47 Belgrave Square, London SW1X 8QX

Brit. J. Hist. Sci. 6 no. 24. Price $£ 2 \cdot 00$. Free to Members of the Society. Published December 1973 